\title{
High Grade Transformation
}

National Cancer Institute

\section{Source}

National Cancer Institute. High Grade Transformation. NCI Thesaurus. Code C161018.

Dedifferentiation of a malignant neoplasm. 